\title{
Stabil Angina Pektoris Hastalarında Tiyol/Disülfid Homeostazı Analizi
}

\section{An Analysis of Plasma Thiol/Disulphide Homeostasis in Patients with Stable Angina}

\author{
${ }^{1}$ Hayrullah YAZAR, ${ }^{2}$ Esra YILDIZ, ${ }^{3}$ Mustafa Baran INCI, ${ }^{4}$ Mehmet Akif CAKAR, ${ }^{5}$ Betul OZBEK, \\ ${ }^{5}$ Ceylan BAL, ${ }^{5}$ Ozcan EREL
}

\author{
Sakarya University Faculty of Medicine, Department of Biochemistry, Sakarya, Turkey Sakarya \\ ${ }^{2}$ University Faculty of Art and Sciences, Institute of Natural Sciences, Sakarya, Turkey \\ ${ }^{3}$ Istanbul Public Health Directorate, Istanbul, Turkey \\ ${ }^{4}$ Sakarya University Faculty of Medicine, Department of Cardiology, Sakarya, Turkey \\ ${ }^{5}$ Yildirim Beyazit University, Faculty of Medicine, Department of Medical Biochemistry, Faculty Member and Turkey Academy of Sci- \\ ences (TUBA) Member, Ankara, Turkey
}
Hayrullah Yazar: https://orcid.org/ 0000-0001-9447-6322
Esra Yildiz: https://orcid.org/0000-0001-8456-3502
Mustafa Baran Inci: https://orcid.org/0000-0003-1893-5368
Mehmet Akif Cakar: https://orcid.org/0000-0003-3216-4205
Betul Ozbek: https://orcid.org/0000-0003-3355-7801
Ceylan Bal: https://orcid.org/0000-0002-1678-1281
Ozcan Erel: https://orcid.org/0000-0002-2996-3236

\section{ÖZ}

Amaç: Stabil angina pektoris tanılı hastaların tiyol/ disülfid homeostazını incelemektir.

Materyal ve Metot: Çalışma populasyonu 85 stabil angina pektoris hastası ile, 31 sağlıklı gönüllüden oluşmaktadır. Hasta ve kontrollerin tiyol/disülfid değerlerini karş1laştırmak için Erel ve Neşelioğlu tarafından yeni geliştirilen analiz metodu kullanılmıștır. Her iki grup için disülfid /total tiyol, serbest tiyol/total tiyol ve disülfid/serbest tiyol değerleri hesaplanmıştır.

Bulgular: Çalışmada elde edilen disülfid, serbest tiyol ve total tiyol değerleri sırasıyla; hasta grubu için $18.00 \mu \mathrm{mol} /$ $\mathrm{L}, 365,08 \mu \mathrm{mol} / \mathrm{L}, 401,10 \mu \mathrm{mol} / \mathrm{L}$ ve kontrol grubu için 9,67 $\mu \mathrm{mol} / \mathrm{L}, 372,51 \mu \mathrm{mol} / \mathrm{L}, 391,85 \mu \mathrm{mol} / \mathrm{L}$ şeklinde bulunmuştur. Bu çalışma ile, stabil angina pektoris hastalarının tiyol/disulfid plazma değerleri yeni geliştirilen metot ile ilk defa belirlenmiștir. Disülfid, disülfid/serbest tiyol ve disülfid/total tiyol değerleri kontrole göre hasta grubunda anlamlı şekilde yüksek çıkarken; serbest tiyol/ total tiyol değeri hastalarda anlamlı şekilde düşük çıkmiştır $(\mathrm{p}<0,001)$.

Sonuç: Tiyol ve disülfit değerleri stabil anjina pektoris hastalarında yüksek düzeyde görülebilir, bu nedenle tiol/ disülfid homeostazı bu hastalık için bir gösterge olabilir.

Anahtar Kelimeler: Serbest tiyol, total tiyol, disülfid, tiyol/disülfid, stabil angina

\section{ABSTRACT}

Objective: To investigate thiol/disulfide homeostasis in patients with stable angina pectoris.

Materials and Methods: The study population consisted of 85 stable angina pectoris patients and 31 healthy volunteers. To compare the thiol/disulfide values of the patients and controls, the newly developed analysis method was used by Erel and Neselioglu. Disulfide/total thiol, free thiol/total thiol and disulfide/free thiol values were calculated for both groups.

Results: Disulfide, free thiol and total thiol values obtained in the study were; $18.00 \mu \mathrm{mol} / \mathrm{L}, 365.08 \mu \mathrm{mol} / \mathrm{L}$, $401.10 \mu \mathrm{mol} / \mathrm{L}$ for the patient group and $9.67 \mu \mathrm{mol} / \mathrm{L}$ for the control group, $372.51 \mu \mathrm{mol} / \mathrm{L}, 391.85 \mu \mathrm{mol} / \mathrm{L}$ for the control group. It is the first time thiol/disulphide homeostasis in plasma was examined by new developed method in stable angina pectoris patients with this study. Disulfide, disulfide/free thiol and disulfide/total thiol values were significantly higher in the patient group compared to the control group. free thiol/total thiol levels were significantly lower in patients $(\mathrm{p}<0.001)$.

Conclusion: Thiol and disulfide values can be seen at high levels in patients with stable angina pectoris, so thiol/ disulfide homeostasis may be an indicator for this disease. Keywords: Native thiol, total thiol, disulphide, thiol/ disulphide, stable angina pectoris
Sorumlu Yazar / Corresponding Author:

Hayrullah Yazar

Sakarya University Faculty of Medicine, Department

Biochemistry, Sakarya, Turkey Sakarya

Phone: 5323179702

E-mail: drhyazar@hotmail.com
Yayın Bilgisi / Article Info:

Gönderi Tarihi/ Received: 04/09/2019

of Kabul Tarihi/ Accepted: 03/04/2020

Online Yayın Tarihi/ Published: 30/06/2020

Atıf / Cited: Yazar H, et al. An Analysis of Plasma Thiol/Disulphide Homeostasis in Patients with Stable Angina. Online Türk Săgllk Bilimleri Dergisi 2020;5(2):318-323. doi: 10.26453/otjhs.615454

\section{INTRODUCTION}

Stable angina pectoris is severe constriction of coronary arteries and atherosclerotic ischemia result.
Heart muscle could not get enough oxygen feeding due to narrowing vessels by atherosclerotic plaque formation. ${ }^{1}$ 
Stable angina pectoris attack occurs when many factors come together such as sex, age and life style. Place of pain, duration of pain, character of pain and relation with exercise are criteria in diagnoses in stable angina pectoris. Symptomatic alleviation is associated with drug treatment like antiischemic drugs and lifestyle. ${ }^{2}$

Oxidative stress, imbalance between oxidants and antioxidants system, have role in cardiovascular disease. Namely; oxidative stress enhances the formation of plaque from macrophages by modifying low density lipoprotein (LDL), called oxidized LDL (ox-LDL). Ox-LDL combines with the monocytes and foam cells are formed, role in formation of atherosclerotic plaque by linking smooth muscle cells and thrombus formation. ${ }^{3}$ In previous studies, it is concluded oxidative stress promotes coronary artery disease. ${ }^{4}$ The major cause of stable angina is narrowing coronary artery due to atherosclerosis triggered by oxidative stress.

Thiol is an organic compound, found in blood plasma as albumin, cystein and glutathione, includes sulfhydryl group (-SH) and oxidized to disulfide form to detoxificate the endogenous and exogenous reactive oxygen species. The disulfide bonds are reduced to thiol form again by special enzymes and so, the thiol/disulfide homeostasis is found in a balance. ${ }^{5}$ When antioxidant system is disrupted, this thiol/disulfide balance shifts to disulfide form.

There is no method to measure thiol/disulfide homeostasis as calorimetric and duplex until 2014. ${ }^{6}$ By this new method, native thiol, dynamic disulfide, and total thiol levels could be measured more reliable and sensitive. ${ }^{7}$ The relationship between thiol disulfide and oxidative stress has been the subject of research in almost all patient groups. Experimental studies have been carried out in this respect and even new treatment methods have been presented for many diseases such as type 1 diabetes, exercise, preeclampsia, hypertension, acute myocardial infarction and appendicitis. ${ }^{8-14}$ In present study done plasma samples were obtained and used for determining the levels of thiol/disulphide. In addition to after determining native thiol levels, total thiol levels and disulphide levels, disulphide/total thiol percent ratios, native thiol/total thiol percent ratios, and disulfide/native thiol percent ratios were calculated. ${ }^{7}$ The aim of this study is to measure and compare the thiol/disulphide levels of stable angina patients with a control group by a novel, easily, reliable and cheap oxidative stress marker method.

\section{MATERIALS AND METHODS}

Study population: This study was conducted in Sakarya University Faculty of Medicine and Yildirim Beyazit University Faculty of Medicine biochemistry laboratories. The study population with 116 participated was consisted of 85 cases newly diagnosed stable angina pectoris individuals and 31 healthy volunteers. The blood was taken from all the participants with green capped lithium heparinized biochemical tubes $(3 \mathrm{cc}, \mathrm{BD})$ before angina procedure for patient group. The plasma samples, obtained by centrifuge for $10 \mathrm{~min}$ at $1500 \mathrm{rpm}$, were kept in -80 ${ }^{\circ} \mathrm{C}$ (Sakarya University Training and Research Hospital Clinical Biochemistry Laboratory) until working day and were transported to Ankara Ataturk Training and Research Biochemistry Laboratory with dry ice. The present study was conducted in accordance with the Declaration of Helsinki 2013 Brazil version and approved by Sakarya University Ethics Committee (Date: 28.09.2016, decision no: 16214662/050.01.04/123). All participants provided written informed consent prior to participation in this study.

Biochemical parameters: Plasma thiol/disulfide homeostasis was determined with a novel spectrophotometric measurement method, recently developed by Erel \& Neselioglu, by using and automated clinical chemistry analyzer (Roche, Cobas 501, Mannheim, Germany). ${ }^{7}$ The thiol/disulfide homeostasis values were calculated as $\mu \mathrm{mol} / \mathrm{L}$. The principle of the new assay based on reducing with sodium borohydride $\left(\mathrm{NaBH}_{4}\right)$. The free functional thiol group is formed by reducing disulfide bonds with $\mathrm{NaBH}_{4}$. Total thiol group value (-SH+ -S-S-) consists of summation of thiol groups and reduced thiol group. The unused $\mathrm{NaBH}_{4}$ remnants are completely removed by formaldehyde. Thus, this prevents the extra reduction of the 5,5'-dithiobis-(2-nitro benzoic acid) (DTNB) and further reduction of the formed disulphide bond, which are produced after the DTNB reaction. The total thiol content of the sample is measured using modified Ellman reagent. Native thiol (-SH) content is subtracted from the total thiol (-SH+ -S-S-) content and half of the obtained difference gives the disulphide bond (-SS) amount. After measuring native thiol (-SH) levels, total thiol (-SH+ -S-S-) levels directly, disulphide (-SS) levels, disulphide/total thiol percent ratios (-SS/ -SH+ -S-S-), native thiol/total thiol percent ratios $(-\mathrm{SH} /-\mathrm{SH}+-\mathrm{S}-$ $\mathrm{S}-)$, and disulfide/native thiol (-SS / -SH) percent ratios were calculated.

Analytical recovery: The percent recovery of the 
novel method was determined via the addition of $200 \mu \mathrm{M}$ oxidized glutathione to plasma samples. The mean percent recovery was $98-100 \%$.

Linearity: The linearity of the native thiol measurement was the same with that of Ellman's reagent assay. Serial dilutions of the glutathione solution were generated. The upper limit of the linearity for the native thiol measurement was $4000 \mu \mathrm{M}$. Linearity of the total thiol measurement was also dependent on the amounts of NaBH4 and formaldehyde concentrations. Serial dilutions of the oxidized glutathione solution were also generated. The upper limit of the linearity for the disulphide measurement was $2000 \mu \mathrm{M}$. Dilution of plasma samples did not affect the novel assay.

Lower detection limit: The detection limit of the assay was determined by evaluating the zero calibrator 10 times. The detection limit, defined as the mean value of zero calibrator +3 standard deviations (SDs), was $2.8 \mu \mathrm{M}$.

Analytical sensitivity: As the slope of the calibration line, analytical sensitivity was found to be $7.9 \times$ 10-4 Absorbance/Amount, $[\mathrm{A} \times(\mu \mathrm{M})-1]$.

Interference: It was found that haemoglobin, EDTA, citrate and oxalate did not interfere with the assay developed, but bilirubin did negatively interfere with the assay. Lipaemic and uraemic plasma samples did not interfere with the assay. Plasma and serum samples can be used as samples.

Precision: To determine the precision of the novel assay, we assayed three levels of a plasma pool. A plasma pool that had high disulphide levels was obtained from the samples of patients with diabetes mellitus. The plasma pool with medium disulphide levels was obtained from the samples of healthy persons. The plasma pool with low disulphide levels was obtained from the samples of patients with urinary bladder cancer. Percent coefficient variation (\% $\mathrm{CV})$ was $4(\overline{\mathrm{X}}=29.12$ and $\sigma \mathrm{X}=1.2)$ for high levels, 5 $(\bar{X}=16.03$ and $\sigma \mathrm{X}=0.79)$ for medium levels and 13 $(\bar{X}=7.15$ and $\sigma \mathrm{X}=0.98$ ) for low levels.

Statistical analysis: For statistical analyses, Statistical Package for Social Science (SPSS) for windows 20 was performed. Kolmogorov-Smirnov test was used to detect normal distribution of data. Numerical variables with normal distribution were presented as mean \pm standard deviation. Comparison of group's mean values and median values were analyzed by using Independent $t$ test and Mann-Whitney $U$ test. $P<0.05$ was evaluated the significance for statistical analyses.

\section{RESULTS}

For present study the population consisted of 85 stable angina patients and 31 healthy individuals. Table 1 summarized the thiol/disulphide homeostasis parameters for patients $(n=85)$ and control group $(\mathrm{n}=31)$. The most striking of these parameters was disulphide $(18.00 \pm 10.44 \mu \mathrm{mol} / \mathrm{L}, 9.67 \pm 6.14 \mu \mathrm{mol} / \mathrm{L})$ and disulphide/native thiol (\%) (4.99 \pm 2.80 , $2.69 \pm 1.84$ ) values.

Native thiol and total thiol values in the groups were found to be normal distributed. The mean values of native thiol $(\overline{\mathrm{X}}=365.08 \pm 58.97 \mu \mathrm{mol} / \mathrm{L})$ and total thiol $(\overline{\mathrm{X}}=401.10 \pm 64.99 \mu \mathrm{mol} / \mathrm{L})$, according to the independent samples $\mathrm{t}$ test analysis performed between the mean values of native thiol $(\overline{\mathrm{X}}=372.51 \pm 47.29 \mu \mathrm{mol} / \mathrm{L}) \quad$ and total thiol $(\bar{X}=391.85 \pm 46.03 \mu \mathrm{mol} / \mathrm{L})$ no statistically significant differences were found between the mean values $(\mathrm{t}$ $(114)=0.63, p=0.53$ and $\mathrm{t}(114)=-0.85, \mathrm{p}=0.37)$.

The disulphide, disulphide/native thiol (\%), disulphide/total thiol (\%) and native thiol/total thiol (\%) values were not normally distributed. According to the results of the Mann-Whitney U test, there were statistically significant differences between the patient group and the control group in terms of disulphide values. These differences are shown in Table 1 in detail.

As a result the disulphide values; disulphide/native thiol percent ratios and disulphide/total thiol percent ratios obtained from stable angina patients were significantly higher than the control group's values of the same parameters, but native thiol/total thiol percent ratio was found significantly lower than that of the control group.

\section{DISCUSSION AND CONCLUSION}

Stable angina pectoris, characterized with chest pain, can be caused reducing oxygen feeding of heart muscle due to narrowing vessels with atherosclerotic plaques. In this attack, the pain starts chest region and spread through arms and back. Generally, the attack stars with hardly working or emotional stress and physical exertion and lasts a short time about five minutes. The extreme hot or cold weather can affect the stable angina attack. In stable angina patients, prognosis progresses well; the mortality ratio is about $2-3 \%$ and possibility of a myocardial infarction is $2-3 \% .{ }^{13}$ Increasing reactive oxygen species and oxidative stress triggers formation of atherosclerotic plaque by creating ox-LDL. Therefore, stable angina disease and oxidative stress are in 
a close relationship.

Thiol is an important compound in detoxification system of reactive oxygen species by oxidized to disulphide form. Decreasing thiol level and increasing disulphide form can be an indicator of oxidative stress in organism.

Until this new colorimetric method, the dynamic thiol/disulphide balance was measured only onesided. ${ }^{17}$ By this fully automated new, rapid, easy, remarkable and repeatable method, dynamic thiol/ disulphide homeostasis could be measured. ${ }^{8}$ After developing this new method, many diseases, related with oxidative stress, was investigated in terms of thiol/disulphide homeostasis. In a previous study, disulphide/thiol ratio was measured in masked hypertension patients. The disulphide formation was higher in patients than controls. ${ }^{17}$ The same measurement was applied in hyperemesis gravidarum patients and it is concluded that thiol-disulphide balance has shifted to the oxidative side. ${ }^{13}$ According to another previous study used this new colorometric method, disulphide- thiol ratios may be used in foreseeing the level of pre-eclampsia. ${ }^{18}$ This novel indicator of oxidative stress was examined in children with simple febrile seizure and the result has shown that the seizure may cause disruption in favor of disulfide bonds. ${ }^{19}$ In a previous study, Kayacan et al $^{20}$ aimed to evaluate the relationship between exercise and both 1-tyrosine and oxidative stress using this new method and the result showed that exercise positively affected thiol/disulphide homeostasis. Moreover, this prognostic biomarker was applied in non small cell lung cancer patient and total thiol, native thiol and disulphide levels was found decreased in patients. ${ }^{19}$ In our study, the thiol/ disulphide homeostasis results for patients and control group are parallel with previous studies related with other diseases. Thiol/disulphide homeostasis was examined in a population included 85 stable angina patients and 31 healthy controls with the new method, which is the study in literature about thiol/ disulphide homeostasis and stable angina. It is believed that this study can contribute the literature about relationship between stable angina and thiol/ disulphide homeostasis. According to our thiol/ disulphide homeostasis results, disulphide (S-S), disulphide/native thiol (S-S/-SH) and disulphide/ total thiol (S-S/-SS+-SH) values were significantly higher in stable angina patients when compared to control group whereas native thiol/total thiol (-SH/$\mathrm{SS}+-\mathrm{SH})$ ratio was significantly lower. These results indicated that thiol/disulphide homeostasis shift to disulphide side on account of formation of disulphide bond from thiol group due to increasing oxidative stress and reactive oxygen species. Thiol/ disulphide homeostasis is very important parameter for understanding a disturbance in oxidantantioxidant balance because thiol is the most abundant antioxidant molecule in organism and so it can be a good marker. ${ }^{22}$ Therefore, in our study, increased disulphide bond formation and reduced thiol molecule could be an indicator for imbalance antioxidant system in stable angina pectoris patients.

In conclusion, the present study was perfomed by using a newly developed method to analyze thiol/ disulphide homeostasis in stable angina pectoris patients. It is demonstrated that thiol/disulphide homeostasis shift to disulphide bond formation in stable angina pectoris patients due to increasing oxidative stress and thiol oxidation. According to our results, oxidation of thiol and disulphide bond formation could be seen high level in stable angina pectoris pathogeny, so thiol/disulphide homeostasis may be an indicator for this disease.

Ethics Committee Approval: The present study was approved by Sakarya University Ethics Committee (Date: 28.09 .2016$, decision no: 16214662/050.01.04/123).

Conflict of Interest: No conflict of interest was declared by the authors.

Author Contributions: Concept - HY, EY, MBİ; Supervision - ÖE; Materials - HY, EY; Data Collection and/or Processing - MAÇ, MBİ; Analysis and/ or Interpretation - ÖE, BÖ, BC; Writing - HY, EY.

Peer-review: Externally peer-reviewed.

\section{REFERENCES}

1. Valgimigli M, Biscaglia S. Stable angina pectoris. Curr Atheroscler Rep. 2014;16(7):422. doi: 10.1007/s11883-014-0422-4

2. Collet C, Capodanno D, Onuma Y, et al. Left main coronary artery disease: pathophysiology, diagnosis, and treatment. Nat Rev Cardiol. 2018;15(6):321-331.

3. Bonomini F, Tengattini S. Atherosclerosis and oxidative stress. Histol Histopathol. 2008;23 (3):381-390. doi: 10.14670/HH-23.381

4. Dzau VJ, Antman EM, Black HR, et al. The cardiovascular disease continuum validated: clinical evidence of improved patient outcomes: part I: Pathophysiology and clinical trial evidence (risk factors through stable coronary artery disease). 
Circulation. 2006;114(25):2850-2870.

5. Jones DP, Liang Y. Measuring the poise of thiol/ disulfide couples in vivo. Free Radical Bio Med. 2009;47(10):1329-1338. doi: 10.1016/ j.freeradbiomed.2009.08.021

6. Winther JR, Thorpe C. Quantification of thiols and disulfides. BBA-Gen Subjects. 2014;1840 (2):838-846. doi:10.1016/j.bbagen.2013.03.031

7. Erel O, Neselioglu S. A novel and automated assay for thiol/disulphide homeostasis. Clin Biochem. 2014;47(18):326-332. doi:10.1016/ j.clinbiochem.2014.09.026

8. Ates I, Kaplan M, Yuksel M, et al. Determination of thiol/disulphide homeostasis in type 1 diabetes mellitus and the factors associated with thiol oxidation. Endocrine. 2016;51(1):47-51. doi: 10.1007/s12020-015-0784-6

9. Ozler S, Erel O, Oztas E, et al. Serum thiol/ disulphide homeostasis in preeclampsia. Hypertens Pregnancy. 2015;34 (4):474-485. doi: 10.3109/10641955.2015.1077859

10. Erkus ME, Altiparmak IH, Akyuz AR, et al. The association between plasma thiol levels and left ventricular diastolic dysfunction in patient with hypertension. Scand J Clin Lab Inv. 2015;75 (8):667-673.

11. Ergin M, Cendek BD. Dynamic thiol-disulfide homeostasis in hyperemesis gravidarum. J Perinatol. 2015;35(10):788-792. doi: 10.1038/ jp.2015.81

12. Kundi H, Ates I, Kiziltunc E, et al. A novel oxidative stress marker in acute myocardial infarction; thiol/disulphide homeostasis. Am J Emerg Med. 2015;33(11):1567-1571. doi: 10.1016/ j.ajem.2015.06.016

13. Ozyazici S, Karateke F, Turan U, et al. A novel oxidative stress mediator in acute appendicitis: Thiol/disulphidehomeostasis. Mediators Inflamm. 2016;10(2):1-6.

14. Kayacan Y, Yazar H, Cerit G, Ghojebeigloo BE. A new oxidative stress indicator: Effect of 5hydroxytryptophan on thiol-disulfide homeostasis in exercise. Nutrition. 2019;63(64):114-119. doi: 10.1016/j.nut.2019.01.013

15. Silver MT, Rose GA, Paul SD, et al. A clinical rule to predict preserved left ventricular ejection fraction in patients after myocardial infarction. Ann intern med. 1994;121(10):750-756. doi:10.7326/0003-4819-121-10-19941115000004

16. Ellman G, Lysko H. A precise method for the determination of whole blood and plasma sulfhy- dryl groups. Anal Biochem. 1979;93(1):98-102.

17. Ates I, Ozkayar N, Altay M, et al. Is disulphide/ thiol ratio related to blood pressure in masked hypertension?. Clin Exp Hypertens. 2016;38 (2):150-154.

18. Yuvaci HU, Akdemir N, Bostanci MS, et al. Evaluation of the level of thiol-disulphide homeostasis in patients with mild and severe preeclampsia. Pregnancy Hypertens. 2016;6(4):394399. doi: 10.1016/j.preghy.2016.09.003

19. Elmas B, Erel Ö, Ersavaş D, Yürümez Y. Thiol/ disulfide homeostasis as a novel indicator of oxidative stress in children with simple febrile seizures. Neurol Sci. 2017;38(11):1969-1975. doi: 10.1007/s10072-017-3087-2

20. Kayacan Y, Yazar H, Kisa EC, Ghojebeigloo BE. A novel biomarker explaining the role of oxidative stress in exercise and 1-tyrosine supplementation: thiol/disulphide homeostasis. Arch Physiol Biochem. 2018;124(3):232-236. doi: 10.1080/13813455.2017.1388410

21. Dirican N, Dirican A, Sen O, et al. Thiol/ disulfide homeostasis: A prognostic biomarker for patients with advanced non-small cell lung cancer?. Redox Rep. 2016;21(5):197-203. doi: 10.1179/1351000215Y.0000000027

22. Erel O. A novel automated direct measurement method for total antioxidant capacity using a new generation, more stable ABTS radical cation. Clin Biochem. 2004;37(4):277-285. doi: 10.1016/j.clinbiochem.2003.11.015 
Table 1. Thiol/disulphide homeostatic parameters for stable angina and control groups.

\begin{tabular}{|c|c|c|c|}
\hline & Control $(n=31)$ & Stable Angina $(n=85)$ & $p$ value \\
\hline Native thiol $(\mu \mathrm{mol} / \mathrm{L})$ & $372.51 \pm 47.29$ & $365.08 \pm 58.97$ & $0.53 *$ \\
\hline Total thiol $(\mu \mathrm{mol} / \mathrm{L})$ & $391.85 \pm 46.03$ & $401.10 \pm 64.99$ & $0.37 *$ \\
\hline Disulphide $(\mu \mathrm{mol} / \mathrm{L})$ & $9.67 \pm 6.14$ & $18.00 \pm 10.44$ & $<0.001 * *$ \\
\hline Disulphide/native thiol (\%) & $2.69 \pm 1.84$ & $4,99 \pm 2.80$ & $<0.001 * *$ \\
\hline Disulphide/total thiol (\%) & $2.49 \pm 1.60$ & $4.43 \pm 2.23$ & $<0.001 * *$ \\
\hline Native thiol/total thiol (\%) & $95.01 \pm 3.20$ & $91.14 \pm 4.47$ & $<0.001 * *$ \\
\hline
\end{tabular}

* Independent samples $t$ test was used for comparing the differences between the arithmetic mean values of groups. $p<0.5$ was considered as statistically significant for analyses.

** Mann-Whitney $U$ test was used for comparing the differences between the median values of groups. $p<0.5$ was considered as statistically significant for analyses. 